\title{
Larval development of the Iberian cyprinid Anaecypris hispanica
}

\author{
Carlos Carrapato $^{1, *}$ and Filipe Ribeiro ${ }^{2,3,4}$
}

${ }^{1}$ Instituto da Conservação da Natureza e Biodiversidade, Departamento de Gestão de Áreas Classificadas do Sul, Parque Natural do Vale do Guadiana, Rua D. Sancho II, n. ${ }^{\circ}$ 15, 7750-350 Mértola, Portugal.

2 Museu Nacional de História Natural, Universidade de Lisboa, Rua da Escola Politécnica 58, 1269-102 Lisboa, Portugal.

3 Virginia Institute of Marine Science, School of Marine Science, Department of Fisheries Science, Gloucester Point, 23062 Virginia, USA.

${ }^{4}$ Centro de Oceanografia, Laboratorio Marítimo da Guia, Facultade de Ciencias da Universidade de Lisboa, Campo Grande, 1749-016 Lisboa, Portugal (current address).

* Corresponding author: carrapatomertola@gmail.com

Received: $27 / 1 / 2011$

Accepted: 10/6/2011

\begin{abstract}
Larval development of the Iberian cyprinid Anaecypris hispanica

Anaecypris hispanica is the most threatened cyprinid fish in the Iberian Peninsula. The distribution of this Iberian cyprinid is restricted to the Guadiana River drainage and a single tributary in the Guadalquivir River and has been rapidly diminishing over the past thirty years. Several A. hispanica populations have been depleted to a point which individual densities are below a level where adults can be detected, making it necessary to identify A. hispanica larvae to assess populations and to make declarations about local extinctions. This work is the first detailed description of the larval stages of A. hispanica from egg to stage 5 observed from laboratory-reared specimens. The eggs are spherical, adhesive, and transparent, and they measure $1.4 \mathrm{~mm}$ (mean diameter). The larvae hatch 72 hours after activation and measure $5.0 \mathrm{~mm}$ (mean total length-TL). The notochord flexion occurs at $5.9 \mathrm{~mm}$ (mean TL), and larvae have 38-39 total myomeres. Anaecypris hispanica larvae have little cephalic pigmentation with few melanophores anterior to the eyes, although pigmentation intensifies during development. Identifying features are presented here that will enable researchers to distinguish A. hispanica from other sympatric species. This information will allow us to identify larvae and can help to assess whether this species is present at locations where adults are not detected.
\end{abstract}

Key words: Larvae stages, Jarabugo, melanophores, myomeres.

\section{RESUMEN}

\section{Desarrollo larvario del ciprínido ibérico Anaecypris hispanica}

El jarabugo, Anaecypris hispanica es el pez ciprínido más amenazado de la Península Ibérica. La distribución de este endemismo ibérico, restringido a la cuenca del Guadiana y a un afluente del Guadalquivir, ha disminuido dramáticamente en los últimos treinta años. Varias poblaciones de A. hispanica se han reducido a niveles inferiores a la detección de adultos por lo que se hace imprescindible la identificación de las larvas de A. hispanica antes de declarar la extinción local. El presente trabajo es la primera descripción detallada de los estados larvarios de A. hispanica, desde el huevo hasta la fase 5 con especímenes criados en laboratorio. Los huevos son esféricos, adhesivos, transparentes y miden 1.4 mm (diámetro medio). Las larvas eclosionan 72 horas después de la activación y miden $5.0 \mathrm{~mm}$ (longitud total-TL media). La flexión del notocordio se produce a los $5.9 \mathrm{~mm}$ (TL media) y las larvas tienen 38 a 39 miómeros en total. Las larvas de Anaecypris hispanica presentan escasa pigmentación en la región preocular, aunque ésta se intensifica durante el desarrollo. Las características únicas que se presentan aquí permitirán su identificación respecto de las especies simpátricas y nos permitirá evaluar si esta especie sigue estando presente en los lugares donde los adultos no fueron detectados.

Palabras clave: Estadios larvarios, jarabugo, melanoforos, miómeros. 


\section{INTRODUCTION}

The highly endangered Jarabugo (or Saramugo in Portuguese; Leunda et al., 2009), Anaecypris hispanica (Steindachner), is a freshwater fish endemic to some tributaries of the Guadiana and Guadalquivir rivers, in the southwestern Iberian Peninsula (Fig. 1) (Doadrio, 2002; Cabral et al., 2005; De Miguel et al., 2010). Thirty years ago, A. hispanica inhabited rivers across the entire middle and lower Guadiana drainage (CollaresPereira \& Almaça, 1979), but its abundance and geographic range have been progressively diminishing (Collares-Pereira et al., 1999). Recently, several A. hispanica populations in this region have been depleted to densities below the level where adults can be detected (Cardoso \& Carrapato, 2008). Therefore, there is an urgent need to assess whether A. hispanica still exists and reproduces in areas where it was previously caught. Individuals at earlier life stages (larvae) are more abundant relative to adult forms and thus might be easier to detect. Therefore identifying larvae rather than adults for population assessments might provide more reliable information regarding population status a local level (Humphries \& Lake, 2000). This is an advantageous method for detecting rare and endangered species, specifically in populations where individual densities are below a level where adults can be detected. Additionally, the detection of larval fish of rare species provides information about reproductive activity and suitable reproductive habitats (Humphries \& Lake, 2000).

This cyprinid is a small (max. Total Length $[\mathrm{TL}]=70-80 \mathrm{~mm})$, short-lived $(\max .2+$ in wild populations) fish that reaches maturity at a small size (39 mm, Fork Length) at one year of age and reproduces between April and May (Ribeiro et al., 2000; Collares-Pereira et al., 2007). This species primarily feeds on zooplankton and algae (Rodríguez-Jiménez, 1987; Collares-Pereira et al., 1998), but studies have been restricted to small scales over space and time. At present, the only data on larval fish stages of endemic Iberian cyprinids come from an unpublished description (Carvalho, 2001) of Iberochondrostoma lusitanicum (Collares-Pereira). Therefore, noth-

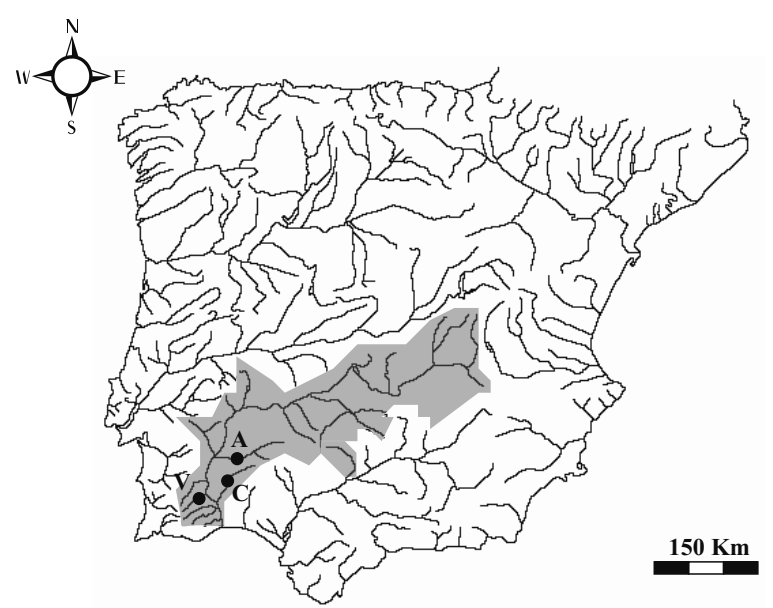

Figure 1. Map of the Iberian Peninsula with Anaecypris hispanica distribution (shaded area), with rescued populations in 2005 (A-Ardila river, C-Chança river, V-Vascão river) that provided specimens for this work. Distribución de Anaecypris hispanica en la Península Ibérica (área sombreada), con poblaciones rescatadas en 2005 (A-río Ardila, C-río Chança, V-río Vascão) que proporcionaron muestras para este trabajo.

ing is known about $A$. hispanica early developmental stages despite the fact that other aspects of its biology have been studied, including its basic biology (Collares-Pereira et al., 1998; Ribeiro et $a l ., 2000$ ) and population genetic structure (Alves et al., 2001; Salgueiro et al., 2003). The aim of the present study is to provide descriptions of the early life stages of A. hispanica that will enable identification of this endangered species through future larval studies.

\section{METHODS}

\section{Parental fish collection}

Adults of A. hispanica were rescued from summer refugia during severe drought conditions in 2005-2006 by the Instituto da Conservação da Natureza e Biodiversidade (ICNB-Portuguese Nature Conservancy Agency; Rogado et al., 2005). These individuals belong to three different populations from the lower Guadiana drainage (Salgueiro et al., 2003) (Fig. 1), which were kept separately while in captivity. The fish were acclimated to room temperature and fed daily with commercial dry food. In 2007, a sample of 
eight fish from the River Chança was used to perform crossing experiments (Carrapato, 2008). Fish ranged in size between 32 and $68 \mathrm{~mm}$ TL and were kept in $120 \mathrm{~L}$ aquaria with an area of $0.3 \mathrm{~m}^{2}$ covered by gravel. This aquarium was subjected to a fixed photoperiod of 12 hours of light and water temperatures ranged between $20^{\circ} \mathrm{C}$ and $23^{\circ} \mathrm{C}$. Ammonium and nitrite were managed using external biologic filtration and nitrate build-up was prevented through periodic partial water changes.

\section{Rearing method and measurements}

Egg masses were promptly removed with a pipette to a rearing aquarium. The rearing aquarium had a $10 \mathrm{~L}$ capacity with no substrate; the water was maintained at a temperature of approximately $22^{\circ} \mathrm{C}\left( \pm 1{ }^{\circ} \mathrm{C}\right)$ and was aerated with an air stone. Larvae were fed daily with artificial food (Nobil Fluid Artemia spp. of JBL) and newly hatched Artemia sp. nauplii were raised in captivity under controlled conditions. Eggs and lar- val fish were collected on specific days (Table 1) and fixed in $4 \%$ formaldehyde; specimens were rinsed in water and preserved in $70 \%$ ethanol for storage in the National Natural History Museum, ichthyological collections 'Museu Bocage' (Accession numbers MB55-0108-MB55-0117). The number of fish euthanized was kept to a minimum (maximum of three individuals per period of collection, Table 1). The authors considered it unethical to sacrifice any more individuals because it is a threatened species (Cabral et al., 2005). These specimens did not cover all the developmental stages, so a previously preserved specimen (16.7 mm, TL) from experiments conducted in 2006 was used to complete the developmental series of specimens, obtained in 2008 because these latter specimens did not cover the entire period of development. The number of eggs and hatched larvae were determined to assess hatch rate (\% of eggs that hatch). Embryonic development was recorded using a stereoscope with digital camera. Fish larvae total length was measured from the tip of the snout to the edge of the

Table 1. Anaecypris hispanica larval stages. Day of observation post-hatch (DPH) and number of larvae observed between brackets, Mean Total Length (TL, mm) or mean egg diameter $(*)$, Number of myomeres (pre-anal + post-anal = total) and ontogenetic events. Etapas larvarias de Anaecypris hispanica. Día de observación después de la eclosión (DPH) y número de larvas observadas entre paréntesis, media de longitud total $(T L, \mathrm{~mm})$ o diámetro de los huevos (*), Número de miómeros (pre-anal + post-anal = total) y eventos ontogenéticos.

\begin{tabular}{|c|c|c|c|c|}
\hline Stage & DPH & $\begin{array}{c}\text { TL }(\mathbf{m m}) \\
{[\text { min-max] }}\end{array}$ & Myomeres & Ontogenetic events \\
\hline Egg & D0 (3) & $1.4 *$ & 一 & - \\
\hline Free embryo & D3 (3) & $\begin{array}{l}5.0 \\
{[4.9-5.1]}\end{array}$ & & $\begin{array}{l}\text { Pear shape yolk sac; no swimbladder, inexistent } \\
\text { mouth opening and gut not fully extended, straight } \\
\text { notochord, no fin anlage }\end{array}$ \\
\hline Stage 1 & D6 (3), D9 (2), D12 (3) & $\begin{array}{c}5.9 \\
{[5.7-6.4]}\end{array}$ & $24+14 / 15=38 / 39$ & $\begin{array}{l}\text { Swimbladder present, mouth opened, onset of ex- } \\
\text { ogenous feeding (algae at day 10), straight noto- } \\
\text { chord, no fin anlage, intensification of pigmenta- } \\
\text { tion }\end{array}$ \\
\hline Stage 2 & D18 (3), D24 (3), D30 (3) & $\begin{array}{l}7.0 \\
{[5.7-8.0]}\end{array}$ & $21+16 / 17=37 / 38$ & $\begin{array}{l}\text { Notochord flexion, caudal fin formation (fin an- } \\
\text { lage and ray formation), caudal and anal fin an- } \\
\text { lage, phototaxy, zooplankton feeding }\end{array}$ \\
\hline Stage 3 & D45 (3), D60 (3) & $\begin{array}{l}8.9 \\
{[7.8-9.9]}\end{array}$ & $21+16 / 17=37 / 38$ & $\begin{array}{l}\text { Caudal fin completion (fin ray segmentation), dor- } \\
\text { sal and anal fin rays formation }\end{array}$ \\
\hline Stage 4 & - & - & - & Not analyzed because the lack of specimens \\
\hline Stage 5 & - & 16.7 & $21+16 / 17=37 / 38$ & $\begin{array}{l}\text { Fully formed fins, extensive pigmentation on } \\
\text { body, remnant fin folder in the body }\end{array}$ \\
\hline
\end{tabular}


Egg

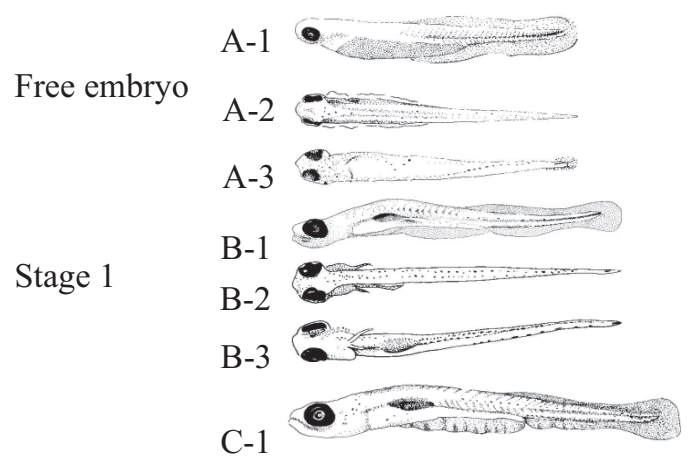

Adult

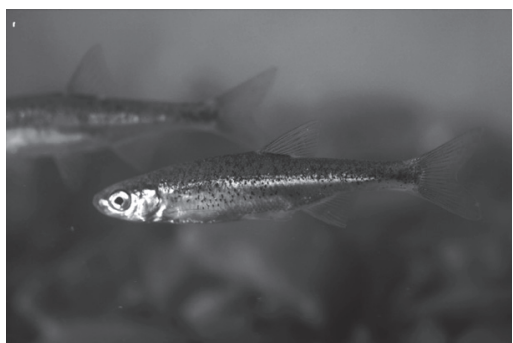

Stage 2

Stage 3

D-2

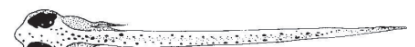

C-2

$\mathrm{C}-3$

D-1
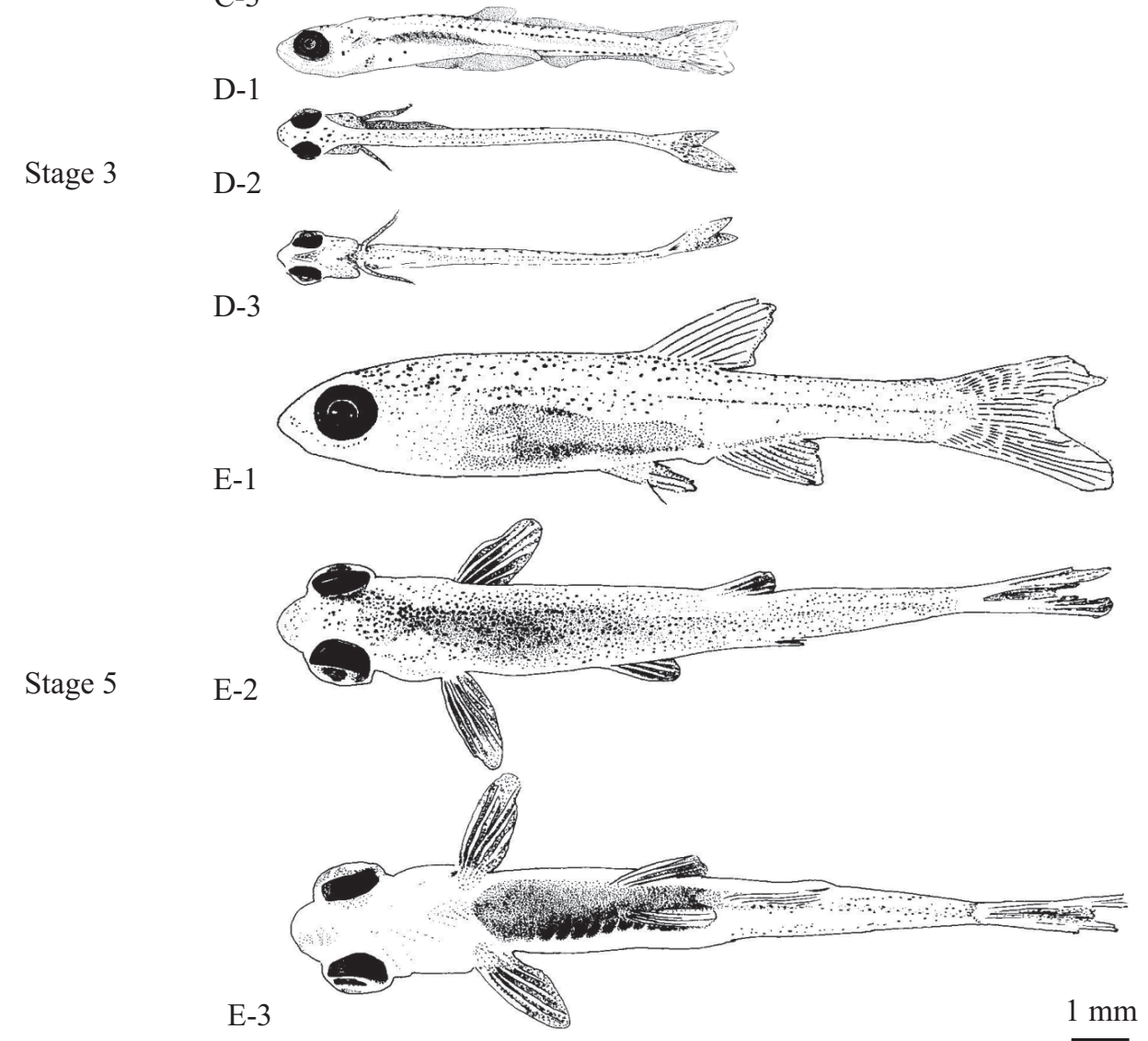

Figure 2. Adult (photo by Carlos Carrapato), Egg, and Larval stages of Anaecypris hispanica. Egg, $1.4 \mathrm{~mm}$ (mean diameter). Free embryo, A-5.0 mm Total Length (TL); Stage 1, B-5.9 mm TL; Stage 2, C-7.0 mm TL; Stage 3, D-8.9 mm TL; Stage 5, E-16.7 mm TL. 1-lateral, 2-dorsal, 3-ventral views. Bar represents $1 \mathrm{~mm}$. Illustrations by Nádia Torres. Adultos (fotografía de Carlos Carrapato), huevos, y estadios larvarios de Anaecypris hispanica. Huevo, $1.4 \mathrm{~mm}$ (diámetro medio). Embriones libres, A-5.0 mm de longitud total (TL); Estadio 1, B-5.9 mm de TL; estadio 2, C-7.0 mm de TL; estadio 3, D-8.9 mm de TL; fase 5, E-16.7 mm de TL. Puntos de vista: 1-lateral, 2-dorsal, 3-ventral. Barra indica $1 \mathrm{~mm}$. Ilustraciones de Nádia Torres. 
caudal fin fold at a precision of $0.1 \mathrm{~mm}$. Larval specimens of Anaecypris hispanica were staged following Pinder \& Gozlan (2004).

\section{RESULTS}

Spawning took place on 2 June 2008 in two distinct egg batches constituting a total of 69 eggs. Eggs are adhesive, transparent, spherical shaped, and have a diameter of $1.4 \pm 0.0 \mathrm{~mm}$ (mean \pm standard deviation). The embryos lack melanophores, have developed and pigmented eyes and the head is developed but lacking a mouth opening. Fin fold, notochord and myomeres are evident. The light orange yolk is visible, has no oil globule, and is concentrated in a sphere just behind the head (Fig. 2-Egg). A total of 55 larvae hatched on June 5th, three days after activation, representing an overall hatch rate of $79.7 \%$.

The free embryo stage lasts at least three days after hatching; at this time, larvae showed little movement and remained at the bottom of the aquarium. At $5.0 \pm 0.1 \mathrm{~mm}$ TL, fish larvae do not have a developed swimbladder, the mouth is not opened, and the gut is not yet extended to the anus (Fig. 2-A). Larvae have pelvic buds, a pear-shaped yolk sac along the body, a straight notochord and fin folds do not show any signs of fin anlage. There is little pigmentation, with a few sparse dendritic melanophores on the dorsal surface of the body and round cephalic melanophores. Few scattered melanophores are present in the posterior part of the yolk and on the ventral side of the post-anal area (Fig. 2-A). Stage 1 begins with the opening of the mouth, which enables the inflation and development of the swimbladder and marks the onset of exogenous feeding. This stage ends with the flexion of the notochord. At this stage, there is no evidence of fin development, and the notochord is straight (Fig. 2-B). During stage 1, mean TL remains constant at $5.9 \pm 0.2 \mathrm{~mm}$ (Fig. 3), and the total number of myomeres is $38-39$, of which 24 are pre- and 14-15 are post-anal. Four days after hatching $A$. hispanica larvae fill the swimbladder the water surface and at day six swim actively and have a developed swimbladder. The mouth is initially in a sub-terminal position but larvae at day 12 it is turned upward in a terminal position. The gut has some remains of yolk at day 6 , but by day 10 , algae are evident in the gut, and larger unidentified food items are observed at day 12. At this time, the gut is coiled anterior to the swimbladder. During stage 1, larvae present an increasing intensification of the pigmentation patterns. Larvae develop a pair of small, circular melanophores that lie dorsally relative to every two myomeres, which lie anterior to the future dorsal fin insertion; these melanophores are dendritic posterior to the dorsal fin area. On the ventral part of the post-anal region, the number of circular melanophores increases, and during this stage, the dendritic melanophores spread and join. The head has few melanophores, which are mostly located posterior to the eyes. The swimbladder has dendritic melanophores located dorsally, whereas the lateral surface and heart

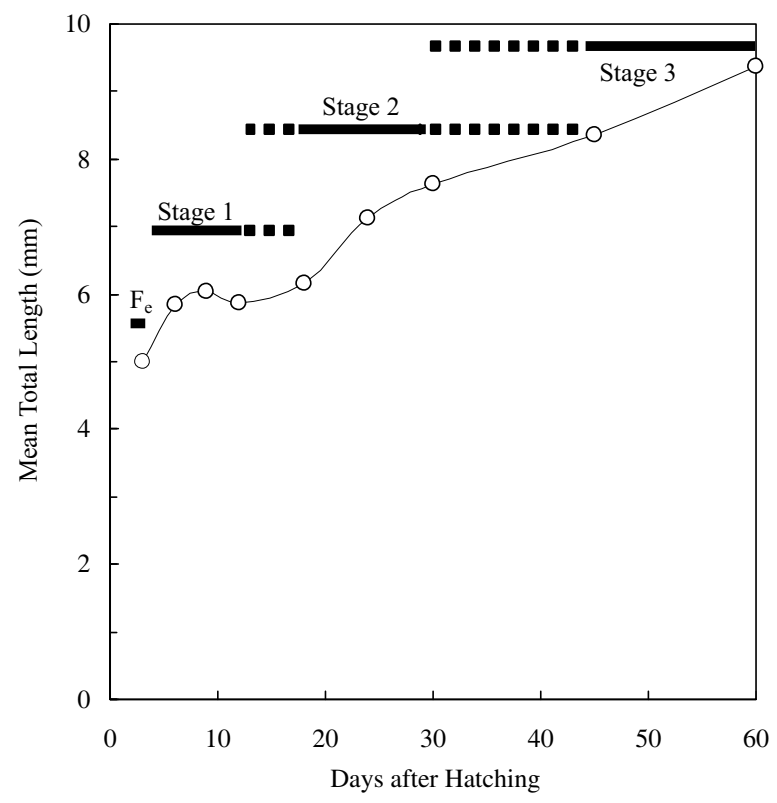

Figure 3. Mean Total Length (mm) of Anaecypris hispanica larvae after days of hatching with the respective larval stages: Fe-Free Embryo, stage 1, stage 2 and stage 3; solid line represents effective stage period while dashed line represent possible stage limits. Media de la longitud total $(\mathrm{mm})$ de las larvas de Anaecypris hispanica después de los días de eclosión con las respectivas etapas larvarias: Fe-embriones libres, etapa 1, etapa 2 y la etapa 3; línea sólida representa la fase más eficaz periodo mientras que la línea discontinua representa los posibles límites del estadio. 
area are sparsely pigmented (Fig. 2-B). During larval stage 1 , pigmentation intensifies, lateral melanophores begin to form a line along the body, and the number of cephalic and ventral melanophores increases.

Stage 2 starts at day 18, when the A. hispanica larvae notochord inflects upward and the caudal fin anlage is clearly visible. This stage ends when the caudal fin rays form a forked caudal fin (Fig. 2-D). During stage 2, larvae increase considerably in size to $7.0 \pm 0.7 \mathrm{~mm}$ TL (Fig. 3). Positive phototaxy was observed at this stage. The number of pre-anal myomeres decreases to 21 , whereas post-anal myomeres increase to 1617; this change is due to a reduction in gut length. At day 24, fin anlage is observed on dorsal and anal fins, although it is less clear in the former. Additionally, the lower lobe caudal-fin rays are beginning to form under the inflected notochord. Thirty-day-old larvae present a square caudal fin with a few melanophores between the fin rays. Pigmentation is similar to the previous stage except that the ventral pigment on the post-anal area extends along the gut. Larvae have more melanophores laterally and ventrally, forming lines along the body. The first cephalic melanophores appear anterior to the eyes, located in the upper jaw (Fig. 2-C). Zooplankton prey are visible in the gut at day 30 .

Stage 3 larvae are characterized by the completion of the fully forked caudal fin, and this stage ends with the full formation of dorsal and anal fins. Larvae increase considerably in TL to $8.9 \pm 0.8 \mathrm{~mm}$ (Figs. 2-D and 3). At day 45, A. hispanica larvae have a fully forked and developed caudal fin, the dorsal fin rays are partially developed, and the anal fin anlage is evident. Sixty-day-old larvae have incomplete dorsal and anal fin rays, whereas caudal fin rays are segmented (Fig. 2-D).

A specimen preserved in 2006 was used to describe one additional larval stage, stage 5, which begins when all the fins are fully formed and ends with the formation of the lateral line (Fig. 2-E). The specimen analysed was $16.7 \mathrm{~mm}$ TL and displayed intense pigmentation on its dorsal surface, including the head. Pigmentation was almost absent from the snout, which had a few punctuate, small melanophores (Fig. 2-E). At stage 5, the myomeres had developed a w-shape.

\section{DISCUSSION}

This paper constitutes the first description of the early developmental stages in Anaecypris hispanica and represents one of the first studies on Iberian cyprinids, with the exception of larval descriptions of I. lusitanicum by Carvalho (2001). The current work will permit the identification of A. hispanica larvae and will provide information about the species status and reproduction in populations with low numbers of adult fish.

The present paper followed the nomenclature presented by Pinder \& Gozlan (2004), which presented five stages for larvae of Leucaspius delineatus (Heckel), although several other authors present other schemes for larval development (e.g., Kendall et al., 1984; Penaz, 2001). Unfortunately, low numbers of analysed specimens $(N=29)$ associated with larvae mortality throughout the study period prevented the description of stage 4. According to Pinder \& Gozlan (2004), stage 4 of cyprinid larval development is typically characterized by the development and completion of pelvic and pectoral fin rays, anal and dorsal fin ray segmentation, and the intensification of pigmentation. The low number of specimens available also limited our ability to determine the precise timing of larval stage transitions, although our contribution enables the identification of A. hispanica at several larval stages.

The number of total myomeres observed in larval A. hispanica (38-39 myomeres) approximately corresponds with the total number of vertebrae, 40-42 (Bogutskaya \& Collares-Pereira, 1997), consistent with the approximate correspondence in number of these structures in fishes (Patterson \& Johnson, 1995; Gemballa et al., 2003). Overall myomere counts can be used to identify different genera of the same family (e.g., Auer, 1982), whereas pigmentation patterns distinguish larval species occurring in a wide array of taxonomic characters (Economou et al., 1994; Pinder, 2001). Scarce pigmentation in the two early larval stages (free embryo and stage 1) 
was observed but became more intense as they grew. Pigmentation intensification during development seems to be associated with behavioral changes (e.g., when fish larvae begin to utilize new environments and require camouflage from predators; Pinder \& Gozlan, 2004). The scarce pigmentation on the snout and dorsal area distinguishes it from other Iberian cyprinid genera such as Squalius and Iberochondrostoma (Carrapato
\& Ribeiro, unpublished data; Carvalho, 2001). Squalius alburnoides (Steindachner), the most closely related Iberian cyprinid (Gromicho et al., 2006), has large melanophores on the cephalic and dorsal region early in its development (Carrapato \& Ribeiro, unpublished data) (Fig. 4).

Larvae of Anaecypris hispanica are distinctive from other cyprinids present in Iberian fresh waters due to low myomere counts $(<40)$, which

A

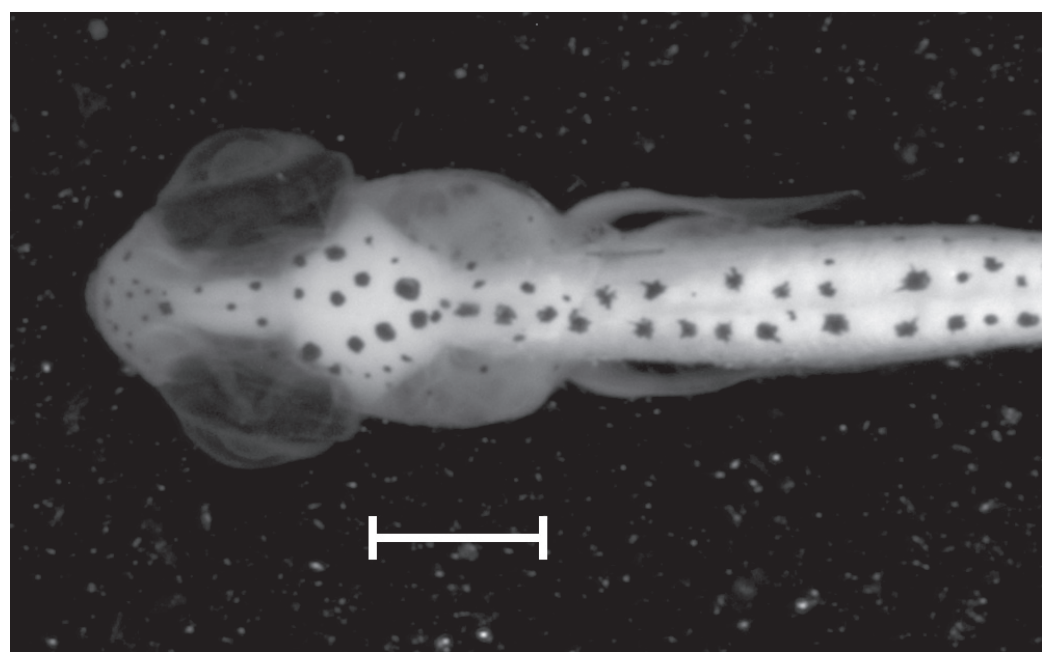

B

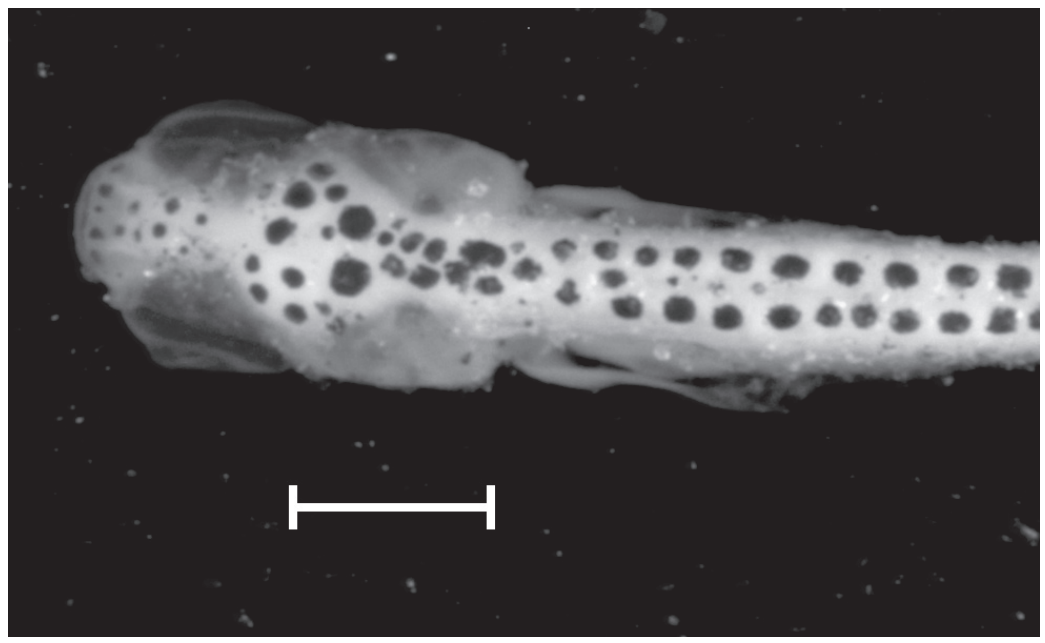

Figure 4. Dorsal view of the head pigmentation of stage 3 larvae of Anaecypris hispanica (A) and Squalius alburnoides (B), bar represents $0.5 \mathrm{~mm}$. Vista dorsal de la pigmentación cefálica del estado 3 en larvas de Anaecypris hispanica (A) y de Squalius alburnoides (B), la escala representa $0.5 \mathrm{~mm}$. 
distinguish them from the genera Barbus and Pseudochondrostoma (Pinder, 2001; Ribeiro, unpublished data). The eggs of Anaecypris hispanica have a smaller diameter $(1.4 \mathrm{~mm})$ than I. lusitanicum (1.9 mm; Carvalho (2001). Iberochondrostoma lusitanicum has a longer period between activation and hatching (6 days) compared to that of $A$. hispanica, but the durations of the free embryo, stage 1 and stage 2 are approximately the same (Carvalho, 2001).

The development of A. hispanica was relatively slower than a closely related species- $L$. delineatus (Heckel) (Cunha et al., 2002; Pinder \& Gozlan, 2004), due to the lower rearing temperatures used for $A$. hispanica $\left(22^{\circ} \mathrm{C}\right.$ versus $24.7{ }^{\circ} \mathrm{C}$ used by Pinder \& Gozlan, 2004). KorwinKossakowski (2008) demonstrated that optimal temperatures for larval development in European cyprinids are generally higher $\left(>28^{\circ} \mathrm{C}\right)$ than those commonly used, suggesting that the rearing temperature in the current study was not adequate. In fact, the water temperatures in the Guadiana drainage during the late spring are higher than the rearing temperatures we used. Consequently, the development of A. hispani$c a$ in nature is likely faster than what we observed, and higher rearing temperatures should be used in future experiments.

The size increase of $A$. hispanica over time and through different stages (Fig. 3) supports the saltatory theory of development (Balon, 1979). Specifically, stage 1 larvae do not seem to change in total length, though soon after notochord flexion occurs (onset of stage 2), the total length appears to increase (Fig. 2). Notochord flexion is associated with behavioral changes in other cyprinid larvae, Chondrostoma toxostoma (Vallot) and L. delineatus, where swimming capacity increases through searching for food and avoiding predators (Gozlan et al., 1999; Pinder $\&$ Gozlan, 2004). The final period of developmental stage 2 for A. hispanica larva suggests a stabilizing growth rate before another growth rate increase during stage 3 (Fig. 3), supporting the idea that development at early stages occurs in steps (Balon, 1979).

Lack of information about larval fish development is symptomatic across several regions of the world (e.g., Schmidt \& Daniels, 2004; Close et al., 2005) where there is limited research on the larval ecology of freshwater fishes. Despite advances in freshwater fish larvae descriptions (e.g., Gozlan et al., 1999; Pinder, 2001; Pinder \& Gozlan, 2004), these studies were restricted to Central Europe. This study hopes to stimulate larval fish descriptions in the Iberian Peninsula, where information is urgently needed because of high levels of endemism and conservation issues (Economou et al., 1994; Smith \& Darwall, 2006).

\section{ACKNOWLEDGMENTS}

This study was conducted under permits from the Institute for Nature Conservation and Biodiversity (140/2007/DET). The Portuguese Science Foundation supported F. Ribeiro (SFRH/BPD/46761/2008). H. F. Gante and A. Verissimo provided useful comments on early drafts of this manuscript. The authors appreciate insightful revisions provided by E. J. Hilton, T. Clardy and other lab mates at VIMS. Thanks are due to A. C. Cardoso, T. Navarro, O. P. Silva and the F. M. Romba for assistance in the experiment. We are deeply indebted to Nádia Torres for the artwork.

\section{REFERENCES}

ALVES, M. J., H. COELHO, M. J. COLLARES-PEREIRA \& M. M. COELHO. 2001. Mitochondrial DNA variation in the highly endangered cyprinid fish Anaecypris hispanica: importance for conservation. Heredity, 87: 463-473.

AUER, N. A. 1982. Identification of Larval Fishes of the Great Lakes Basin with Emphasis on the Lake Michigan Drainage. Great Lakes Fishery Commission. Ann Arbor MI. 744 pp.

BALON, E. K. 1979. The theory of saltation and its application in the ontogeny of fishes: steps and thresholds. Environ. Biol. Fish., 4: 97-101.

BOGUTSKAYA, N. G. \& M. J. COLLARES-PEREIRA. 1997. Redescription of the Iberian cyprinid Anaecypris hispanica with comments on its taxonomic relationships. Ichth. Expl. Fresh., 7: 243256. 
CABRAL, M. J., J. ALMEIDA, P. R. ALMEIDA, T. R. DELLINGER, N. FERRAND DE ALMEIDA, M. E. OLIVEIRA, J. M. PALMEIRIM, A. I. QUEIROZ, L. ROGADO \& M. M. SANTOSREIS. 2005. Livro Vermelho dos Vertebrados de Portugal. Instituto da Conservação da Natureza. Lisboa. 660 pp.

CARDOSO, A. C. \& C. CARRAPATO. 2008. Intervenção Saramugo 2008. Parque Natural do Vale do Guadiana, Instituto da Conservação da Natureza. $29 \mathrm{pp}$.

CARVALHO, V. 2001. Padrões de actividade e de distribuição espacial, reprodução e desenvolvimento embrionário e larvar em Chondrostoma lusitanicum Collares-Pereira, 1980. Master's Thesis. Instituto Superior de Psicologia Aplicada. 49 pp. + anexes.

CARRAPATO, C. 2008. Ensaios de manutenção e reprodução de saramugos (Anaecypris hispanica Steindachner, 1866) em sistemas fechados. Parque Natural do Vale do Guadiana, Instituto da Conservação da Natureza. 45 pp.

CLOSE, P. G., B. J. PUSEY \& A. H. ARTHINGTON. 2005. Larval description of the sympatric species, Craterocephalus stercusmuscarum stercusmuscarum (Pisces: Atherinidae) and Mogurnda adspersa (Pisces: Eleotridae) from tropical streams of north-east Queensland, Australia. J. Fish Biol., 66: 668-684.

COLLARES-PEREIRA, M. J. \& C. ALMACA. 1979. Pseudophoxinus hispanicus (Steind. 1866), Cyprinidae nouveau pour le Portugal. Bull. Mus. Natl. Hist. Nat. Paris, (4e Ser.) 1 (Sect. A): 285287.

COLLARES-PEREIRA, M. J., A. M. PIRES, M. M. COELHO \& I. G. COWX. 1998. Towards a conservation strategy for Anaecypris hispanica, the most endangered non-migratory fish in Portuguese streams. In: Stocking and Introduction of Fish. I. G. Cowx (ed.): 437-449. Fishing News Books. Blackwell Science. Oxford.

COLLARES-PEREIRA, M. J., I. G. COWX, J. A. RODRIGUES, L. ROGADO \& L. M. COSTA. 1999. The status of Anaecypris hispanica in Portugal: problems of conserving a highly endangered Iberian species. Biol. Conserv., 88: 207-212.

COLLARES-PEREIRA, M. J., A. F. FILIPE \& L. MOREIRA DA COSTA. 2007. Os Peixes do Guadiana Que Futuro? Guia de Peixes do Guadiana Português. Edições COSMOS. Alpiarça. 294 pp.
CUNHA, C., N. MESQUITA, T. E. DOWNLING, A. GILLES \& M. M. COELHO. 2002. Phylogenetic relationships of Eurasian and American cyprinids using cytochrome $b$ sequences. J. Fish Biol., 61: 929-944.

DE MIGUEL, R., E. PINO, A. RAMIRO, F. ARANDA, J. P. PEÑA, I. DOADRIO \& C. FERNÁNDEZ-DELGADO. 2010. On the occurrence of Anaecypris hispanica (Steindachner, 1866), an extremely endangered Iberian endemism, in the Guadalquivir River basin. J. Fish. Biol., 76: 14541465.

DOADRIO, I. (Ed.) 2002: Atlas y Libro Rojo de los Peces Continentales de España. $2^{\mathrm{a}} \mathrm{ed}$. Dirección Gerneral de Conservación de la Naturaleza. Museo Nacional de Ciências Naturales. Madrid. 364 pp.

ECONOMOU, A. N., C. H. DAOULAS, T. H. PSARRAS \& R. BARBIERI-TSELIKI. 1994. Freshwater larval fish from Lake Trichonis (Greece). J. Fish Biol., 45: 17-35.

GEMBALLA, S., L. EBMEYER, K. HAGEN, T. HANNICH, K. HOJA, M. ROLF, K. TREIBER, F. VOGEL \& G. WEITBRECHT. 2003. Evolutionary transformations of myoseptal tendons in gnathostomes. Proc. R. Soc. Lond., B 270: 1229-1235.

GOZLAN, R. E., G. H. COPP \& J. N. TOURENQ. 1999. Early development of the sofie, Chondrostoma toxostoma. Environ. Biol. Fish., 56: 67-77.

GROMICHO, M., M. M. COELHO, M. J. ALVES, \& M. J. COLLARES-PEREIRA. 2006. Cytogenetic analysis of Anaecypris hispanica and the relationship with the paternal ancestor of the diploidpolyploid Squalius alburnoides complex. Genome, 49: 1621-1627.

HUMPHRIES, P. \& P. S. LAKE. 2000. Fish larvae and the management of regulated rivers. Regul. River, 16: 421-432.

KENDALL, A. W. JR., E. H. AHLSTROM \& H. G. MOSER. 1984. Early life history stage of fishes and their characters. In: Ontogeny and Systematics of Fishes. American Society of Ichthyologists and Herpetologists. H. G. Moser, W. J. Richards, D. M. Cohen, M. P. Fahay, A. W. Jr. Kendall \& S. L. Richardson (eds.): 11-22. Lawrence. KS.

KORWIN-KOSSAKOWSKI, M. 2008. The Influence of Temperature During the Embryonic Period on Larval Growth and Development in Carp, Cyprinus carpio L., and Grass Carp, Ctenopharyngodon idella (Val.): Theoretical and Practical Aspects. Arch. Pol. Fish., 16: 231-314. 
LEUNDA, P., B. ELVIRA, F. RIBEIRO, R. MIRANDA, J. OSCOZ, M. J. ALVES, \& M. J. COLLARES-PEREIRA. 2009. International Standardization of Common Names for Iberian Endemic Freshwater Fishes. Limnetica, 28: 189-202.

PATTERSON, C. \& G. D. JOHNSON. 1995. The intermuscular bones and ligaments of teleostean fishes. Smith. C. Zool., 559: 1-85.

PEŇÁZ, M. 2001. A general framework of fish ontogeny: a review of the ongoing debate. Folia Zool., 50: 241-256.

PINDER, A. C. 2001. Keys to larval and juvenile stages of coarse fishes from fresh waters in the British Isles. Freshwater Biological Association. Ambleside. $136 \mathrm{pp}$.

PINDER, A. C. \& R. E. GOZLAN, 2004. Early ontogeny of sunbleak. J. Fish Biol., 64: 762-775.

RIBEIRO, F., I. G. COWX, \& M. J. COLLARES-PEREIRA. 2000. Life history traits of the endangered Iberian cyprinid Anaecypris hispanica and their implications for conservation. Arch. Hydrobiol., 149: 569-586.

RODRIGUEZ-JIMENEZ, A. J. 1987. Relaciones tróficas de una comunidad íctica, durante el estío en el rio Aljucen (Extremadura-España). Miscell. Zool., 11: 249-256.

ROGADO, L., A. C. CARDOSO \& C. CARRAPATO. 2005. Resumo dos trabalhos efectuados pelo Instituto da Conservação da Natureza (ICN), para a monitorização da ictiofauna na Bacia do Guadiana para avaliação e minimização dos efeitos da seca, de 15 de Junho a 30 de Setembro de 2005. Parque Natural do Vale do Guadiana, Instituto da Conservação da Natureza. 30 pp.

SALGUEIRO, P., G. CARVALHO, M. J. COLLARES-PEREIRA \& M. M. COELHO. 2003. Microsatellite analysis of genetic population structure of the endangered cyprinid Anaecypris hispanica. Portugal: implications for conservation. Biol. Conserv., 109, 47-56.

SCHMIDT, R. E. \& R. A. DANIELS. 2004. Description of the larval stages of the Shield Darter, Percina peltata (Pisces: Percidae), in New York. Zootaxa, 774: 1-7.

SMITH, K. G., \& W. R. T., DARWALL. 2006. The Status and Distribution of Freshwater Fish Endemic to the Mediterranean Basin. IUCN-The World Conservation Union: Gland. Switzerland. $31 \mathrm{pp}$. 